\title{
Bilingualism and language attitude in Melilla (Spain)
}

\section{Lotfi Sayahi and Miguel Ángel Montero Alonso}

This study examines levels of bilingualism and language attitude in the autonomous Spanish city of Melilla. Located on the North African coast, Melilla has a population of 86,000 inhabitants that is roughly divided between residents of Iberian origin and residents of North African Origin. Based on responses to a language questionnaire (111 participants) and sociolinguistic interviews (20 participants), our results show high levels of bilingualism between Spanish and Tamazight among the sector of the population that is of North African origin, while the population of Iberian origin remains monolingual in Spanish. We also show that Spanish is the dominant language in the public domain, including administration and education, while Tamazight is maintained as a family and community language. Overall, the participants in our study express positive attitude towards the Melillan variety of Spanish and Tamazight, and their coexistence as part of the multicultural nature of the city.

Keywords: Melilla, Spanish, Tamazight, Arabic, bilingualism, language attitude.

Bilingüismo y actitud lingüística en Melilla (España). Este estudio examina los niveles de bilingüismo y la actitud lingüística en la ciudad autónoma de Melilla. Situada en la costa norteafricana, Melilla tiene una población de 86.000 habitantes que se divide aproximadamente entre residentes de origen peninsular y residentes de origen norteafricano. Basándonos en las respuestas a una encuesta (111 participantes) y entrevistas sociolingüísticas (20 participantes), nuestros resultados muestran altos niveles de bilingüismo entre el español y el tamazight en la población de origen norteafricano, mientras que la población de origen peninsular es monolingüe en español. También muestran que el español es el idioma dominante en el ámbito público, incluida la administración y la educación, mientras que el tamazight se mantiene como un idioma del hogar y la comunidad. En general, los participantes de nuestro estudio expresan una actitud positiva hacia la variedad melillense del español y el tamazight, y su convivencia como parte de la naturaleza multicultural de la ciudad.

Palabras clave: Melilla, español, tamazight, árabe, bilingüismo, actitud lingüística. 


\section{Introduction}

This study analyses the language situation in Melilla, one of the two autonomous Spanish cities embedded in the Moroccan coast. A first objective is to describe the extent of bilingualism in the city and the domains of use of the majority language, Spanish, and the ethnic minority language, Tamazight (Berber). A second objective is to analyse the use of and attitude towards these two languages, in addition to Arabic, the language that is closely associated with the religion of the ethnic Berber community. A third and final objective is to examine attitude towards bilingualism and the outcome of language contact in this context of a European city on the African continent.

Language contact in border communities has attracted a fair number of studies. In addition to a strong focus on contact phenomena such as code-switching, lexical borrowing, and morphosyntactic convergence (Sayahi 2018), some researchers have examined language attitude and language ideologies and their impact on language maintenance and language shift (Pauwels 2016). In the case of Spanish, several studies have focused on language attitude among Hispanics in the Southwest of the United States. Results often show that closer ties with Mexico and proximity to the border is a determining factor in fostering bilingualism and positive language attitudes (Bills et al. 1995; Villa and Rivera-Mills 2009; among others).

Melilla is an interesting laboratory for the study of language contact and language attitude not only for its history-the Spanish occupied Melilla in 1497 and the city has remained a part of Spain since then - but also for several other reasons: its size is small (12.3 square kilometres), it is geographically detached from mainland Spain and surrounded by Morocco and the Mediterranean Sea, and it has a population that is made up of comparable numbers of residents of Peninsular Spanish origin and residents of Berber Moroccan origin, 86,026 people in total (Instituto Nacional de Estadística 2017). Furthermore, a clear religious division exists along the visible ethnic line by which, overwhelmingly, the section of the population that is of an Ethnic European origin, descendants of settlers from the Iberian Peninsula, is Christian while the second group, made up of Ethnic Berbers who are the native inhabitant of North Africa, is Muslim. In addition, there are smaller numbers of Jewish and Hindu residents that add to the religious and multicultural diversity of the city. 


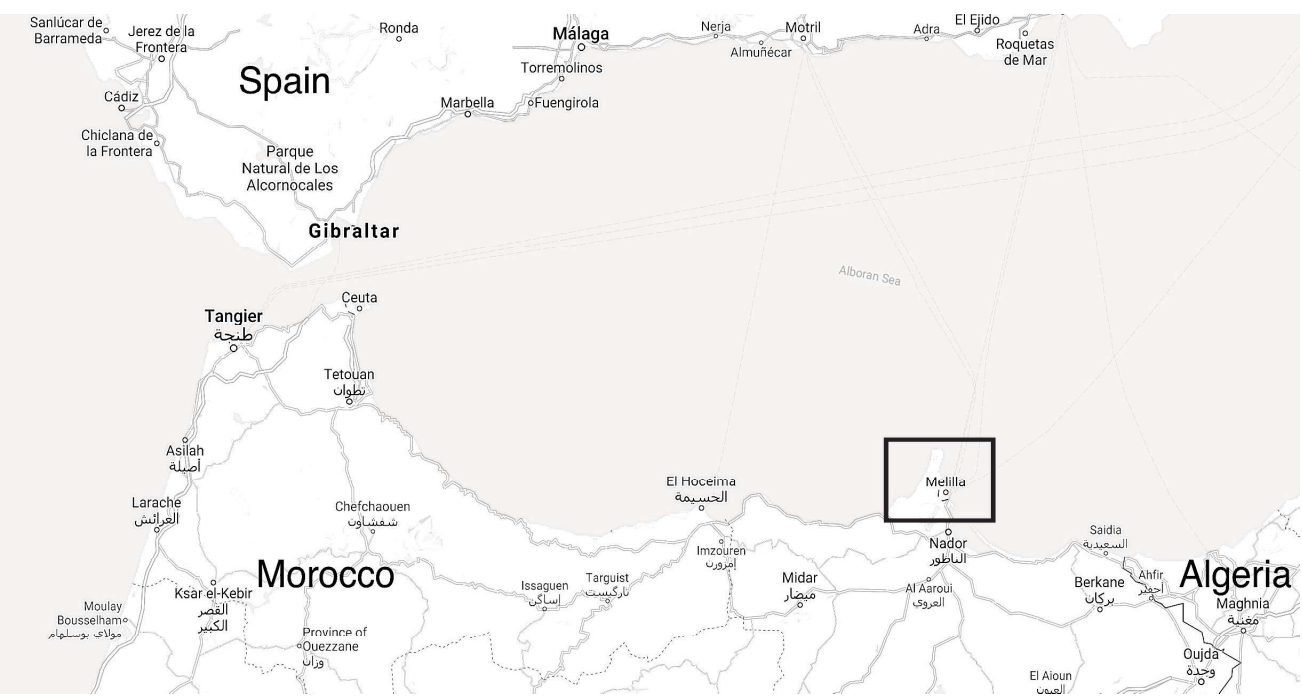

Map 1: Geographical Location of Melilla (Source: Map data (02020 Inst. Geogr. Nacional)

Since the turn of the century, Melilla has attracted the growing attention of Spanish public opinion and media. It is marked by the highest unemployment rate in Spain, reaching 29,5\% in 2017 (Expansión 2017) and is frequently in the news for its position as an entry point for non-European migration (Carr 1997). It has also been referred to as the first Spanish city to reach a majority of Muslim population since the end of the Muslim presence in Spain five centuries ago (Diario Público, November 11, 2009). While 69\% of the total Spanish population identify themselves as Catholics, Melilla has the lowest percent in the country reaching only $46,3 \%$ (La Vanguardia, April 2, 2015).

Based on this ethno-religious division, the inhabitants of Melilla can be divided into three groups of Spanish speakers. The first group are the speakers of Spanish of Ethnic European origin. These speakers in their vast majority are comparable to any native speaker in Spain. They do not acquire other languages outside the European languages that are formally taught at school (González Las 1991; Ruiz Domínguez 1997). In addition, these speakers tend to share common features with Andalusian Spanish speakers, including final /s/ weakening. The second group are the speakers of Spanish of Berber origin who were born in the city to Tamazight-speaking parents. In the majority of the cases they are bilingual speakers of Tamazight and Spanish (Tilmatine 2009). One way their variety of Spanish is different from monolingual Spanish speakers has to do with the lower rates of use of the interdental fricative, especially among male speakers (Sayahi and Montero Alonso 2018). The use of the interdental fricative is an overtly prestigious feature in Spanish, and, in Melilla, its absence is often associated with bilingual 
speakers or monolingual speakers of a lower socio-educational level (Ruiz Domínguez 1999). Finally, the third group of speakers are Moroccan immigrants and cross-border workers (trabajadores fronterizos) who are L2 Spanish speakers. These speakers tend to be Tamazight-dominant speakers, with some who are competent in Arabic as well, but their use of Spanish reflects levels of competence that are typical of adult second language acquisition.

Despite the bilingual competence of the Muslim population, the education system is monolingual in Spanish and all Melillans pursue their studies exclusively in that language. Furthermore, all institutions in the city, including health, social services, and the local government operate exclusively in Spanish. Tamazight for all practical purposes is a home and a community language. A considerable number of the Muslim residents in Melilla continue to have family and, in some cases, economic ties with Morocco and rely heavily on Tamazight to interact with Moroccans on the other side of the border.

Briefly, the Berber languages are the autochthonous languages of North Africa, part of the Afroasiatic language family (Applegate 1970; Basset 1952). There are several varieties across North Africa, with some of them achieving official status in recent years (Sayahi 2014). The Berber variety spoken in the Moroccan region surrounding the city of Melilla is known as Riffian Berber, Tarifit or Tamazight as referred to by its speakers (Chtatou 1997). ${ }^{1}$ There are about 2.5 million speakers of Tamazight across northern Morocco. Tamazight does not have an official status in Melilla and Spain does not recognize it, even if it officially adheres to the European Charter for Regional or Minority Languages. The reasons that Spain cites for not recognizing Tamazight, and Moroccan Arabic in the other autonomous city of Ceuta, as minority languages has to do with the argument that these varieties are not standardized.

\section{Methodology}

The data analysed in this paper come from two sets: a large sociolinguistic survey and a number of recorded sociolinguistic interviews. Additional information about each set of data is provided below.

\subsection{Sociolinguistic survey}

A sociolinguistic survey in Spanish was distributed in print among students from the University of Granada's campus in Melilla, which is a 
satellite campus under the direct purview of the main campus in the city of Granada. The Melilla campus offers degrees in humanities, social sciences and education. We aimed at collecting a relatively balanced sample in terms of ethnic group, gender, and level of education that ranges from first year students to master's degree students. In total, 111 participants took part in the survey that was administered on the Melilla campus in 2017. Of those original participants, 57 participants claimed Ethnic European origin and 42 claimed Ethnic Berber origin. In addition, 9 participants claimed a mixed Berber/ European ethnicity, 2 claimed Arab ethnicity and 1 claimed Berber/Arab ethnicity. In the current analysis we discarded the 12 participants who claimed a mixed ethnicity or an Arab ethnicity as our focus here is on comparing the language practices of the two dominant groups in the city of Melilla: Ethnic Europeans and Ethnic Berbers. These participants were excluded since they would have provided outlier data that could have skewed results.

In addition, based on our knowledge of the community and the interviews we conducted, we decided to eliminate all participants who claimed both a European Ethnic identity and some competence in Tamazight. It appears that some participants may have confused ethnicity with nationality and, to avoid any skewing of the data, we have left 7 participants who fall in this group out of the current analysis. It is true that an Ethnic Tamazight who may not have any competence in Berber may have identified himself or herself as European but, based on the trends we saw in the field, it is safe to consider that anybody with some competence in Berber is almost certainly not Ethnic European. This leaves a total of 92 participants in the sample analysed here, with 48 females and 44 males (Table 1).

\begin{tabular}{|l|l|l|l|}
\hline & Ethnic European & Ethnic Berber & Total \\
\hline Female & 30 & 18 & 48 \\
\hline Male & 20 & 24 & 44 \\
\hline Total & 50 & 42 & 92 \\
\hline
\end{tabular}

Table 1: Ethnicity and gender of the sample

The age of the participants is the typical range for college students, between 18 and 39 with only 5 participants above the age of 30 (4.6\%). The survey included 15 background questions that sought information about language competence and use, 11 language attitude questions on a Likert-type scale, and one open-ended question for additional comments. The results of the survey are examined in the next section. 


\subsection{Sociolinguistic interviews}

A total of 20 interviews conducted with speakers of Spanish in Melilla are considered for this study. The duration oscillated between 45 and 60 minutes, with some interviews lasting a little longer or a little less. With the focus of the interviews being on bilingualism, there are 15 Ethnic Berber participants (10 males, 5 females), with 5 Ethnic European monolingual participants ( 2 males, 3 females) serving as a control group. The interviews revolved around life in Melilla, educational and professional experiences, and travels to mainland Spain and Morocco. Data from the interviews will be used to further elaborate qualitatively on the results of the survey.

\section{Linguistic competence and language use}

It is important to reiterate here that identity in this case is interpreted as an index of ethnicity as opposed to nationality, given that all participants are Spanish nationals. In addition, this division between Ethnic European and Ethnic Berbers closely aligns with religious background, as mentioned above. In Melilla, the most frequently used terms when referring to Ethnic Berbers and Ethnic Europeans were musulmanes and cristianos, respectively. By all measures, religion is an important identity marker in the city which is extended to the other much smaller minorities historically present in the city, Jews and Hindus. In the public sphere in Melilla, references to religious denomination are frequent and often fall in line with the official discourse of the local government that brands Melilla as a multicultural and multi-religion city. In our sociolinguistic interviews, the terms musulmanes and cristianos were also the most used terms when referring to the two major ethnic groups in the city. In the following excerpt, a native Ethnic European Melillan outlines both her awareness of the existence of the ethno-religious differences but, at the same time, her appreciation of it as the one thing she values most about living in the city:

(1) ‘Aquí lo que más ha destacado es la religión. Entre las religiones siempre nos hemos respetado todos [...]. Si somos amigos, entonces no importa la religión. Entonces, esta convivencia es muy bonita.' [Ethnic European, female]

'What has stood out the most here is religion. Among religions we have always respected each other [...]. If we are friends, then religion does not matter. So, this coexistence is very beautiful.' 
Despite the small size of the city and the perceived historical diversity, one can see nonetheless that there remains preference by each section of the population to cluster in certain neighbourhoods or what is called 'districts' by the local government (Ciudad Autónoma de Melilla 2019). While the Ethnic European population tends to cluster around the historical downtown and the port, a large sector of the Ethnic Berber population resides in an area known as districts four and five located in the north western part of the city. These districts have a much lower socioeconomic status and they sometimes make the news for civil unrest by their younger residents given the high rates of unemployment. One participant in the interviews puts it this way:

(2) 'Sí, yo vivo en uno de ellos. Y son los, incluso es que no es solo un barrio sino todos los barrios que es lo que tú ves, que son los mal llamados distritos cuarto y quinto se organizan a la vez y venga todos a la calle vamos a quemar contenedores hasta que nos den los trabajos, los planes de empleo que parecen que son la salvación.' [Ethic Berber, male]

'Yes, I live in one of them. And they are, it is not just a neighbourhood but all the neighbourhoods that is what you see from here, which are the socalled fourth and fifth districts they get organized at once and come out to the street. Let's burn containers until they give us jobs, the employment plans that seem to be the salvation.'

In our study we opted not ask the participants directly about their districts of residence, given the stigma associated with residing in some of them, but rather about their postal codes which indirectly identified the districts. A first observation is that $70.91 \%$ (39/55) of those who claim no competence at all in Tamazight reside in the same postal code areas that are outside the districts four and five described by the informant above. Despite its small size, results regarding the presence of bilingualism in Melilla concur with previous sociolinguistic studies on the ethnolinguistic vitality of minority groups that show a higher condensation of minority languages in certain neighbourhoods and the impact of population movement and social mobility on the loss of ethnic languages (Bourhis et al. 2009; Ytsma et al. 1994; among many others).

\subsection{Competence in Spanish and Tamazight}

Overall, results regarding levels of competence in Spanish show that $95.65 \%(88 / 92)$ of all participants in the sample claim native competence in Spanish regardless of ethnicity. All those who declare 
their ethnicity to be European state that their level of competence in Spanish is native (50/50). On the other hand, $90.48 \%$ of all those who declare their ethnicity to be Berber (38/42) also claim to be native speakers of Spanish. Only $9.52 \%$ of Berbers (4/42), state that their level of Spanish is advanced and not native. This means that, regardless of ethnicity, the common thing for students at the campus of Melilla is to be an L1 user of Spanish, which in itself is not surprising given that the whole educational system is in Spanish. Even those who grew up bilingual, by the time they reach the university, Spanish, as the sole language of instruction, becomes a dominant language for them as well.

The next question addresses levels of competence in Tamazight. Results show that while all participants claim that they are competent in Spanish, with the great majority of them claiming native competence in the language regardless of ethnicity, Spanish/ Tamazight bilingualism is a phenomenon that is common among Ethnic Berbers and not at all among Ethnic Europeans. Based on the results of the survey, the interviews, and direct observation, it is safe to argue that it would be extremely rare to find an Ethnic European Melillan who has some knowledge of Tamazight. On the other hand, only $11.90 \%$ (5/42) of those who claim an Ethnic Berber identity state that they do not speak any Tamazight. The majority claim they have a native competence in Tamazight $(52.38 \%)$ and the rest $(40.48 \%)$ claim they have some competence that ranges from advanced to basic. To sum up, the majority of Ethnic Berbers are bilinguals while Ethnic Europeans are monolinguals. ${ }^{2}$ There is a statistically significant correlation between ethnicity and bilingualism as shown through a Pearson Chi-Square test $(p=.00)$.

Monolingualism among the Ethnic European population has to do with their limited exposure to Tamazight, its lack of official status, and its overall limited linguistic capital and instrumental value. In fact, not only in Melilla, but even in northern Morocco Spanish speakers have reported the lack of need for them to develop competence in Tamazight or Arabic as the indigenous population usually has a higher competence in Spanish (Sayahi 2004, 2005). On the other hand, Ethnic Berbers show very strong levels of competence in Tamazight which in many cases has to do with growing up in households where children are exposed to Tamazight before schooling. In extract (3), one Ethnic European explains how Berbers tend to make more effort to learn Spanish than Ethnic European do to learn Tamazight:

(3) 'Ellos hacen más esfuerzo que nosotros. Ellos hacen esfuerzo para aprender. Nosotros no, yo lo reconozco.' [Ethnic European, female] 
'They make more effort than us. They make an effort to learn. We do not, I acknowledge it.'

As with any other case of bilingualism and heritage language maintenance and shift, once schooling in the dominant language starts, the domains of use of the heritage language become more restricted (Escobar and Potowski 2015). The following excerpt shows how pressure from the school system contributes to the restriction of the use of Tamazight outside the home:

(4) 'Eso es algo que se escucha. Muchos padres tú les preguntas, te dirán pues sí me ha dicho la profesora que no le hable en tamazight porque mi hijo no está aprendiendo bien el español y eso lleva que, al final, tú te encuentras con una generación que no sabe hablar su propio idioma.' [Ethnic Berber, male]

'That is something that we hear. You ask many parents and they will tell you that, yes, the teacher told me not to speak to him in Tamazight because my son is not learning Spanish well and because of that, at the end, you end up with a generation that does not know how to speak their own language.'

A question that arises from these results is whether the Tamazight speakers have competence in the language because they were born in Morocco. Looking at our data, the answer is a clear no. In fact, of the 42 Ethnic Berber participants only 3 were born in Morocco while $90.48 \%$ were born in Melilla. In addition, only 4 have lived in Morocco for a period longer than 6 months. In turn, 78\% of all Ethnic Europeans were born in Melilla, while the rest were born in other parts of Spain. Additionally, $36 \%$ of the Ethnic European participants have lived in Peninsular Spain for more than 6 months while only $7 \%$ of Ethnic Berbers did so. It is revealing that more Ethnic Berbers have lived for extended periods of time in other parts of Spain than in Morocco, which again stresses the point that our Ethnic Berber participants in their great majority have lived all their life in Melilla.

A final observation about bilingualism in the city is the limited presence of Arabic. As expected, all those who declared a European ethnic identity said they do not speak any Arabic. As for those with Berber ethnic identity, a large part said that either they do not speak Arabic at all $(47.62 \%)$ or that they only have a basic competence $(30.95 \%)$, which is assumed in this case to be related to the religious functions of Arabic in the Muslim community. Only two of the Ethnic Berber participants claimed they have a native competence in Arabic. Extract (5) shows the awareness that Tamazight speakers have 
of the lack of competence in Arabic among Muslim Melillans. The idea that those who are more competent in Arabic tend to come from other areas of Morocco, outside of the Rif region, is also widely shared among Melillans. Nonetheless, this overwhelming lack of competence in Arabic does not limit the positive attitude towards the language and even the desire to develop competence in it. The participant quoted in extract (6) indicates a desire to develop competence in Arabic that appears difficult to achieve given the limited presence of the language in the linguistic market of Melilla beyond its religious functions.

(5) 'Encontrar a alguien de esta zona que hable árabe y no hable tamazight es porque no es de esta zona.' [Ethnic Berber, male]

'To find someone in this area who speaks Arabic and doesn't speak Tamazight it has to be because they are not from around here.'

(6) 'El árabe no lo hablo, nada. Siempre me ha gustado y me arrepiento. Le digo a mi padre lo que siempre me ha gustado es aprender el árabe, pero ¿cómo? Si tú no tienes familia árabe [...], estudias en un país o una ciudad donde se estudia el árabe. Cuando no hay recursos, no hay medios pues no sé cómo.' [Ethnic Berber, male].

'I do not speak Arabic, not at all. I've always liked it and I regret it. I tell my father that what I would have liked is to learn Arabic, but how? If you don't have Arab family members [...] and you don't go to school in a country or a city where Arabic is studied. When there are no resources and there are no means, then I don't know how.'

\subsubsection{Domains of use}

We have shown in the previous section that Spanish is the dominant language, both in institutional terms and in levels of competence. We have also shown that Ethnic Berbers have a strong tendency to develop competence in Tamazight despite its lack of formal status and the fact that the speakers are in their majority native Melillans. In this section, we will address domains of use of Spanish and Tamazight at home and in the community.

\subsubsection{Language use at home}

The use of both Spanish and Tamazight is prevalent among those with some level of competence in Tamazight. In fact, $66.67 \%$ of all Ethnic Berbers claim that they use both Spanish and Tamazight at home 
( $p=.00$ ). In turn, those who use only Tamazight represent $11.90 \%$. As the level of self-reported competence in Tamazight decreases, usage of Spanish by itself increases, reaching $21.43 \%$ of the sample. This means that in Melilla, like in minority communities elsewhere, the home domain is the context where Tamazight is predominant even if the majority's language may be present especially in communication among siblings who are attending the monolingual Spanish schools. With regards to gender, male Ethnic Berbers report a higher rate of use of either Spanish only or Tamazight only at home than females. They use Spanish only in $29.17 \%$ of the cases while females use it at the rate of $5.55 \%$. On the other hand, $16.66 \%$ of male Ethnic Berbers use Tamazight only at home while only $5.55 \%$ of females do so. Female Ethnic Berber participants claim higher rates of use of both languages at home that reaches $88.88 \%$, meanwhile males use both languages at home at the considerably lower rate of $54.16 \%$.

The prevalent use of Tamazight at home explains its intergenerational transmission and accounts for the strong levels of bilingualism discussed above. The use of Tamazight as a home language and the proximity of Tamazight-speaking Morocco are two important factors that contribute towards the high levels of maintenance of Tamazight as a minority language in Melilla. Nonetheless, it is noteworthy that in the case of this bilingual community the use of the dominant language is increasingly becoming more prevalent within the home domain, to the degree that more speakers use Spanish only at home than those who use Tamazight only at home.

\subsubsection{Language use with friends}

Looking at the correlation between levels of competence in Tamazight and its use with friends, it becomes clear that a difference exists between interactions with friends from the university and with friends from outside the university. Regardless of competence in Tamazight, all participants declare that they communicate more in Spanish with their university friends than in Tamazight. In fact, participants who claim a native competence in Tamazight use Spanish only with university friends in $59.09 \%$ of the cases, while they use both Spanish and Tamazight in $40.91 \%$ of the cases. It becomes obvious that the public domain of the university conditions the use of Tamazight only and allows for more usage of both languages. The rates are the opposite when it comes to friends from outside the university as the speakers with native competence in Tamazight use Spanish only in $22.73 \%$ of the cases and use both languages in $72.73 \%$ of the cases. The lower the competence in Tamazight, the higher the dominance of Spanish in 
interactions at the university and outside of it. In the case of speakers with a basic level in Tamazight, use of Spanish with university friends reaches $100 \%$, while use of Spanish only with non-university friends reaches $60 \%$ and use of both languages reaches $40 \%$. With nonuniversity friends, $33.33 \%$ of male Ethnic Berbers claim they use Spanish only while $11.11 \%$ of females claim to do so. On the other hand, only one person in each group claims to use Tamazight alone, while as expected the majority in both cases use Spanish and Tamazight at a rate of $62.5 \%$ for male participants and $83.33 \%$ in the case of female participants. This confirms the results for language use at home where females report more use of both languages than males.

In sum, two factors determine the use of Tamazight outside the home. The first is the role of education, where speakers tend to use more Spanish with their university friends and code-switch between the two languages, depending on their competence in Tamazight. On the other hand, with friends from outside the university, the majority claim more use of both languages as opposed to use of Spanish only. In the case of those with no knowledge of Tamazight, Spanish predominates both inside and outside the university. This highlights the role of education not only in increasing competence in Spanish, but also its use in social contexts and the presence of code-switching which will be addressed in the next section. Outside the home, use of Tamazight by itself is reduced drastically and use of Spanish increases significantly both by itself and alongside Tamazight in bilingual interactions.

\section{Language attitude}

In this section, we explore the attitude of both groups of speakers towards the two languages of Melilla. The purpose is to describe the language ideologies toward Spanish as spoken by the two ethnic groups and towards the perceived results of contact between Spanish and Tamazight. The questions under this section of the survey were formulated using a Likert scale that prompted the participants to choose between: Strongly agree, agree, neither agree nor disagree, disagree, and strongly disagree. In our analysis, where it became pertinent, we grouped the two favourable or unfavourable answers together to clarify the general tendencies towards the issues under discussion.

\subsection{Attitude towards Melillan Spanish}

Seeking to assess the speakers' awareness of Melillan Spanish as a separate variety from other southern Spanish varieties, we asked the 
participants whether they believed Spanish in Melilla is different from the Spanish spoken in other regions of Spain. In total, $82.61 \%$ of all participants agree or strongly agree that there is a distinctive Melillan Spanish variety. During the oral interviews, some speakers state that although they believe their variety is closest to Málaga, they think it is a mixture of Spanish accents that makes it hard for other Spaniards to determine that they are from Melilla based on their dialect alone. As illustrated in the following excerpt (7), participants attribute the origin of the perceived mixed features in the dialect of Melilla to the historically strong civil servants and military personnel influx from other parts of Spain to Melilla.

(7) 'Si yo voy a Madrid me dicen, no eres de Andalucía porque no somos tan cerrados como en Andalucía. El andaluz es muy cerrado. La pregunta siempre es, pero de Castilla tampoco y del norte tampoco. Claro, porque tenemos una mezcla de toda la península en Melilla. Entre los funcionarios que vienen, los militares que vienen, hay muchos militares que vienen, tenemos una mezcla aquí en Melilla de todas las formas de hablar el español.' [Ethnic European, female]

'If I go to Madrid, they tell me, you are not from Andalusia because our accent is not as closed as in Andalusia. The Andalusian dialect is very closed. The question is always you are not from Castile neither and not from the north either. Of course, because we have a mixture of the entire peninsula in Melilla. Because of the public servants that come, the military members that come, there are many members of the military who come, we have a mixture here in Melilla of all the ways of speaking Spanish.'

This awareness that Melillan Spanish is different from other varieties did not stand in the way of a positive attitude towards the local variety. The answer to the statement 'Melillan Spanish is correct' showed that Melillans have a positive opinion about their variety of Spanish with the majority of participants agreeing with the statement or expressing no opinion about the matter. ${ }^{3}$ Unlike many regions in southern Spain where speakers tend to perceive their varieties as inferior to normative varieties of Spanish, and especially central-northern Castilian varieties (Blas Arroyo 2008), in Melilla speakers from both ethnic groups agree that Melillan Spanish is 'correct' at a total of 63.04\%. Ethnic Europeans show a higher positive attitude towards Melillan Spanish with a total of $68 \%$ agreeing that it is 'correct' and an additional 18\% neither agreeing nor disagreeing with the statement. On the other hand, Ethnic Berbers show a lower level, albeit still positive, of agreement that reaches $57.14 \%$ of the participants, while a very significant number of them, $30.95 \%$, neither agree nor disagree. There was no statistically significant 
difference between both groups when it comes to positive attitude towards the local variety of Spanish $(p=.24)$. Those who have lived in other parts of Spain do not seem to think differently from those who lived only in Melilla, as there was no statistically significant correlation between longer period of residency in other parts of Spain and attitude towards the Melillan variety of Spanish $(p=.10)$.

\subsection{Attitude towards Tamazight and bilingualism}

In a question regarding whether the current status of languages in Melilla is satisfactory, the answers were divided between those who agree and those who neither agree nor disagree. In fact, the majority of the participants did not express an opinion. A total of $46 \%$ of Ethnic Europeans neither agreed nor disagreed, while a total of $41.46 \%$ of Ethnic Berbers chose that option. A substantial percent also claim that they agree that the current status is positive: $34 \%$ in the case of Ethnic Europeans and even a higher rate of $43.90 \%$ in the case of Ethnic Berbers. It may be that given the wide spread bilingualism among Ethnic Berbers their perception of the situation is positive, even if that is not reflected or recognized in local policies. Part of the reason for the high rate of those who did not express an opinion may be some ambiguity in the question, a more direct question regarding the lack of official status of Tamazight might have produced clearer trends.

The participants were also asked about their perception of the value of Tamazight in the local linguistic market and if Tamazight is useful beyond communication with family and friends and visiting Morocco. A little more over half of the Ethnic European participants agree that it has value (52\%) while for Ethnic Berbers $61.91 \%$ agree and only $19.05 \%$ disagree. It is interesting that many Ethnic Europeans have positive attitude towards the minority language that not only they do not speak but which is not fully codified or taught at schools. On the other hand, the fact that a substantial sector of the Berber population $(30.09 \%)$ do not see value for the use of Tamazight beyond family and friends is not surprising especially given the little value that Tamazight enjoys in the local linguistic market. This is reflected in a follow-up question that asked whether the participants think 'Tamazight is being lost'. Results, here again, were not drastically different, Ethnic Europeans responded that they agree at a rate of $44 \%$. On the other hand, Ethnic Berbers agreed at a higher rate of $50 \%$. The difference is more significant in the number of participants who chose the option of neither agree nor disagree where 10.95\% more Ethnic Europeans than Berbers chose that option ( $30 \%$ vs. $19.05 \%)$. 
We also asked the participants about their perception of the extent of bilingualism in the city. Regarding the statement 'Many Melillans are bilingual', a significant number of each group agreed: Ethnic Europeans 54\%, and Ethnic Berbers 64.28\%. This confirms the reality of the city where the majority of Ethnic Berbers are bilingual. A second question was about the value of Tamazight for multiculturalism in Melilla. Multiculturalism is a concept that is officially adopted and encouraged by the city's administration, although in many contexts Melillans feel that there are two separate societies. The local government promotes the concept of multiculturalism and there are institutions specifically dedicated to that effort, including the Instituto de las culturas which even offers online courses in Tamazight. The campus of Melilla itself offers an master's degree in multicultural diversity. It is not surprising then that Ethnic Europeans agree at the rate of 50\% that Tamazight is important for multiculturalism with only $22 \%$ disagreeing with that statement. On the other hand, Ethnic Berbers, unsurprisingly, agree at a much higher rate, $71.43 \%$, and disagree at a lower rate $14.29 \%$. There was no statistical difference between both groups with regards to the role of Tamazight in Melilla's multicultural identity $(p=.07)$

\subsection{Attitude towards the outcome of language contact}

When participants were asked if they believe Melillan Spanish in general shows influence from Tamazight, the answers are divided closely between those who agree and those who do not agree with the statement. In the case of Ethnic Europeans, they disagree at the rate of $40 \%$ and agree at $38 \%$. With regards to Ethnic Berbers, they agree that there is influence from Tamazight in the Spanish of Melilla at the rate of $42.85 \%$. On the other hand, $50 \%$ of them do not agree with the statement with only $7.14 \%$ not expressing an opinion.

When we asked the participants if they believe the Spanish spoken by Berbers is different, $42 \%$ of the Ethnic Europeans answered that they do. On the other hand, Berbers believe that their variety of Spanish is different at a rate of only $28.57 \%$. In this case, the majority of Berbers do not think of their variety of Spanish as being different from other Melillans while a substantial part of Ethnic Europeans think that Berbers speak a distinctive variety of Spanish. In the interviews, several Ethnic European speakers referred to what they called el deje bereber 'the Berber accent', with some even claiming that non-Berber youth are starting to speak a similar variety of Spanish to that of the Berber youth. Some participants in the interviews expressed more negative attitude 
towards the perceived influence of Tamazight in Spanish as illustrated in the following extract:

(8) 'El acento? A mí no me gusta porque es como un batiburrillo desgranado, ahí como parece que te van a soltar, te van a hablar en cherja en un momento a otro.' [Ethnic European, male]

'The accent? I do not like it because it's like a broken hodgepodge, it seems that they're going to let go and talk to you in Tamazight at any moment.'

Another participant argues that the reason she thinks the Berber population speaks with a different accent is because they do not use Spanish at home as she puts it:

(9) 'Aunque hayan nacido en Melilla el deje siempre lo tienen [...] porque hablan su idioma en sus domicilios, en sus casas. Solamente hablan el castellano yo creo de puertas para fuera.' [Ethnic European, female]

'Even though they were born in Melilla, they always have the accent because [...] they speak their language in their residences, in their homes. They only speak Spanish, I think, outside.'

This is of course a common perception by monolingual majority members in many contexts who think that bilingualism is the reason for perceived variation in the use of the majority language and low performance in school as reflected in the development of movements such as 'English only' in the United States (Barker et al. 2001; Escobar and Potowski 2015). On the other hand, when asked if Spanish has influence on Tamazight, Ethnic Europeans believe that it is true at $48 \%$. Although this may be surprising given that Ethnic Europeans do not speak Tamazight, it may be caused by their experiences hearing code-switching between both languages. Ethnic Berbers are divided equally when it comes to the statement that Spanish has influence on Tamazight with $45.24 \%$ agreeing with the statement and another $45.24 \%$ disagreeing and the rest $9.52 \%$ neither agreeing nor disagreeing.

Previous studies have shown the existence of heavy code-switching and borrowing in the Tamazight variety spoken in Melilla as a result of contact with Spanish (Tilmatine 2011). In the same line, regarding the effect of language contact, our participants were asked if codeswitching between Spanish and Tamazight is acceptable. We find that only $26 \%$ of the Ethnic European participants agree, while Berber 
participants are more accepting of code-switching at $40.48 \%(p=.22)$. The literature on code-switching is rich with examples where minority members code-switch between their ethnic language and the language of the majority to create a hybrid identity that sets them apart from monolingual speakers of either of their two languages (Auer 2016). In fact, part of the Berber participants' identity construction as Melillans and Muslim Spaniards is the recognition that they code-switch frequently between both of their languages as illustrated by the speaker in (10).

(10) 'Mezclamos, nunca hablamos tamazight puro, mezclamos [...] con el castellano. Metemos siempre palabras que convertimos en tamazight. No sé cómo pero perfectamente nos suenan así.' [Ethnic Berber, female]

'We mix, we never speak pure Tamazight, we mix [...] with Spanish. We always put in words that we turn into Tamazight. I do not know how, but they sound perfectly well that way to us.'

In another quote a different speaker specifically makes reference to the role of religion and the proximity of Berber-speaking Morocco in the frequency of code-switching among Berber Melillans:

(11) 'Pero también, es que también hay que tener en cuenta si es que, por ejemplo, los que son como en mi caso a lo mejor pueden ser de religión musulmana y tienen mucha familia en Marruecos y esta parte cercana del Rif y eso, también como que mezclan el tamazight que, mezclan mucho el tamazight con el español.' [Ethnic Berber, male]

'But also, it is also necessary to take into account, for example, those who are like me, who may be of Muslim religion and have a lot of family in Morocco and this part of the Rif, that they also mix Tamazight, they mix Tamazight with Spanish a lot.'

There was even a case of a speaker we interviewed who compared the situation of code-switching between Spanish and Tamazight in Melilla to what he referred to as 'the problem of Spanglish in the United States.' This illustrates the perception that minority community members themselves have regarding contact phenomena and the feeling that new varieties may emerge in cases of intense language contact, even if that is not necessarily the case (Lipski 2008).

Asked about the future of Tamazight in Melilla, the participants in our study offered a wider range of answers that in a way shows the uncertainty regarding bilingualism in the city in the coming years. A total of $44 \%$ of Ethnic Europeans state that they agree with the 
statement that the use of Tamazight in Melilla is disappearing, while $26 \%$ disagree with it. The rest, a significant $30 \%$, did not have an opinion as they neither agree nor disagree. This is different in the case of the Ethnic Berber participants since those who agree that Tamazight is disappearing reach a significant $50 \%$ while those who disagree represent $30.95 \%$. On the other hand, a total of $19.05 \%$ do not agree or disagree. Among Ethnic Berbers, a more significant percent of the male participants agree that Tamazight is being lost, $62.5 \%$, as opposed to female participants who agree with that statement at only $33.33 \%$. Furthermore, the higher the competence in Tamazight the more concerned the participants are about its future since $45.45 \%$ of those who claim native competence in Tamazight believe it is disappearing.

While, by many measures, the ethnolinguistic vitality of the Tamazight speaking community in Melilla is strong, given their substantial numbers and the proximity with Tamazight-speaking Morocco, many Ethnic Berbers believe it is the Spanish monolingual educational system that is fomenting language shift. This concern about the future of the language in the city is reflected in the following comment by one of the participants. He is doubtful that, despite his own bilingualism, his parents will speak to his own children in Tamazight. This lack of transmission would lead to language shift as he has noticed in the case of some families that have been in Melilla for generations.

(12) 'Porque ya sus abuelos van a ser mis padres, mis padres no creo que se vayan a poner a hablar tamazight con sus nietos, entonces lamentablemente parece que sí. Se va a perder. Sí, sí, está pasando yo creo que en muchísimas familias. Hay algunas que no, que nacen más puros como en barrios como la Cañada que la mayoría son de origen marroquí y que han venido a Melilla hace muy poco tiempo. Pero hay otros barrios que se van modernizando más y van abrazando el castellano y dejando un poquito de lado el tamazight. Y también lo que hace mucho eso es a lo mejor no tener familia en el campo, el no ir a visitar al campo, a tus abuelos o tus tíos lejanos o, no sé, no salir a Marruecos, no salir a Marruecos es lo que está haciendo mucha gente también.' [Ethnic Berber, male].

'Because their grandparents are going to be my parents, I don't think my parents are going to speak Tamazight to their grandchildren, so, unfortunately, it seems that it is the case. It will be lost. Yes, yes, it's happening I think in a lot of families. There are some that do not, those that are born pure, in neighbourhoods like La Cañada where the majority are of Moroccan origin and who have come to Melilla very recently. But there are other neighbourhoods that are modernizing more, and they are embracing 
Castilian and leaving Tamazight a little aside. And, also, what causes a lot of that is maybe not having a family in the countryside, not going to visit your grandparents or your uncles, or not going to Morocco, not going to Morocco is what a lot people are doing too.'

Indeed, multiple studies have shown that the bilingualism of the second generation is a transitional phenomenon that most often leads to severely diminished competence in the heritage language by the third generation (Kagan et al. 2017).

\section{Conclusion}

This study shows that Melillans, regardless of their ethnicity, are in their overwhelming majority native speakers of Spanish. This is so because Tamazight is not recognized by Spain and all public institutions and the educational system operate exclusively in Spanish. Berber participants identify as Spaniards and feel they are native speakers of Spanish because of their dominance in it, especially in reference to educational/formal contexts. In addition, Ethnic Berber Melillans demonstrate a high degree of loyalty to their ethnic language, Tamazight. This is all the more exceptional given the lack of standardization and literacy in Tamazight. Ethnic Berbers, like many bilingual communities, code-switch between Spanish and Tamazight, especially at home and with friends outside the university. Codeswitching between Spanish and Tamazight seems to be one index these speakers use to display their hybrid identity of being Muslim and Spanish at the same time.

Overall, the high levels of competence in Tamazight among members of the Ethnic Berber community, the role Tamazight plays in their identity construction as Muslim citizens of Spain, and the proximity of Morocco, all help sustain a positive attitude towards their ethnic language. Religion has historically been and remains an important vehicle for language maintenance in the city even if Arabic is the language that is most closely associated with the Islamic religion. While this positive picture of the situation is further brightened by the interest by the local government in promoting a multicultural character of the city and the appearance of institutions that are starting to preserve Tamazight and the cultural heritage of the Ethnic Berbers, additional policies seem to be needed to further secure the future of bilingualism in Melilla through governmental policies and bilingual education programs similar to what is found in other regions of Spain. 
Miguel Ángel Montero Alonso
Departamento de Estadística
e Investigación Operativa
Universidad de Granada
mmontero@ugr.es
ORCID: 0000-0002-1214-9035.
Lotfi Sayahi

Department of Languages, Literatures

and Cultures

University at Albany, State University of New York sayahi@albany.edu

ORCID: 0000-0003-1319-9306.

Recepción: 12/05/19; Aceptación: 04/09/2020

\section{Notas}

1 In this paper, the term 'Tamazight' is used to refer to the ethnic language of the Muslim population in Melilla.

2 Acquisition of English as a foreign language is relatively common but the levels of competence do not usually exceed intermediate levels as is typical in many Spanish institutions of higher education.

3 The sentence used in the actual questionnaire was 'El español de Melilla es bueno', as this was how speakers in the community often described their variety.

${ }^{4}$ Cherja is another name for Tamazight.

\section{References}

Applegate, Joseph R. 1970. “The Berber languages,”. In: Current Trends in Linguistics, VI: Linguistics in South West Asia and North Africa, ed. by Thomas A. Sebeok, Charles A. Ferguson, Carleton T. Hodge, Herbert H. Paper, John R. Krueger and Gene M. Schramm, 586-664. The Hague: Mouton

Auer, Peter. 2016. Code-switching in conversation: language, interaction and identity. London: Routledge Taylor and Francis Group.

Barker, Valerie, Howard Giles, Kimberly Noels, Julie Duck, Michael Hecht Hecht, and Richarde Clément. 2001. "The English-Only Movement: A Communication Analysis of Changing Perceptions of Language Vitality". Journal of Communication 51. 3-37.

Basset, André. 1952. La Langue berbère. London, New York: Oxford University Press

Bills, Garland D., Eduardo Hernández Chávez, and Alan Hudson. 1995. "The geography of language shift: distance from the Mexican border and Spanish language claiming in the Southwestern U.S.". International Journal of the Sociology of Language 114: 9-28.

Blas Arroyo, José Luis. 2008. "Variación lingüística e identidad en la España plurilingüe: una aproximación multidisciplinar". In: Selected Proceedings of the 4th Workshop on Spanish Sociolinguistics, ed. by Maurice Westmoreland and Juan Antonio Thomas, 116. Somerville, MA: Cascadilla Proceedings Project.

Bourhis, Richard Y., Annie Montreuil, Geneviève Barrette, and Elisa Montaruli. 2009. "Acculturation and immigrant-host community relations in multicultural settings". In: Intergroup misunderstandings: Impact of divergent social realities, ed. by Stephanie Demoulin, Jacques-Philippe Leyens and John F Dovidio, 39-61. New York, NY: Psychology Press. 
Carr, Matthew. 1997. "Policing the frontier: Ceuta and Melilla". Race E Class 39: 1. 6166.

Chtatou, Mohamed. 1997. "The influence of the Berber language on Moroccan Arabic". International Journal of the Sociology of Language 123: 101-118.

Ciudad Autónoma de Melilla. 2019. "Descripción Actual De MELILlA: Distritos Y Barrios". Accessed 17 February 2019. http://planestrategicomelilla.net/f17_02.htm.

Escobar, Anna Maria, and Kim Potowski. 2015. El Español de los Estados Unidos. Cambridge: Cambridge University Press.

Expansión. 2017. Datosmacros. Accessed 1 March 2019. http://www.datosmacro.com/ccaa/ melilla

González Las, Catalina. 1991. El español en Melilla: fonética y fonología. Melilla: Servicio de Publicaciones del Excmo. Ayuntamiento de Melilla.

Instituto nacional de Estadística. 2016. Población por comunidades y ciudades autónomas $y$ sexo. Accessed 1 March 2019. http://www.ine.es/jaxiT3/Tabla.htm?t=2853\&L=0

Kagan, Olga E. , Maria M. Carreira, and Claire Hitchens Chik. 2017. The Routledge handbook of heritage language education: from innovation to program building. London: Routledge.

La Vanguardia. 2015. "Creencias y prácticas religiosas en España”. Accessed 1 March 2019. https://www.lavanguardia.com/vangdata/20150402/54429637154/interactivocreencias-y-practicas-religiosas-en-espana.html

Lipski, John. 2008. Varieties of Spanish in the United States. Washington, DC: Georgetown University Press.

Pauwels, Anne. 2016. Language maintenance and shift. Cambridge: Cambridge University Press.

Ruiz Domínguez, María del Mar. 1997. Estudio sociolingüístico del habla de Melilla. Universidad de Alcalá de Henares doctoral dissertation.

Ruiz Domínguez, María del Mar. 1999. "El seseo en el habla de la ciudad de Melilla". Lingüística Española Actual 21:1. 127-148.

Ruiz Domínguez, María del Mar. 2001. "El español y el chelja: dos realidades lingüísticas en los hablantes musulmanes de Melilla". Textos de Didáctica de la Lengua y la Literatura 26. 65-74.

Sayahi, Lotfi and Miguel Ángel Montero. 2018. Spanish in contact with Berber: the case of Melilla. Paper presented at the $9^{\text {th }}$ Workshop in Spanish Sociolinguistics (Queens, NY).

Sayahi, Lotfi. 2004. "'Aquí todo el mundo hablaba español': History of the Spanish language in Tangier". Journal of North African Studies 9:1. 36-48.

Sayahi, Lotfi. 2005. "El español en el norte de Marruecos: historia y análisis". Hispanic Research Journal 6:3.195-207.

Sayahi, Lotfi. 2014. Diglossia and Language Contact: Language Variation and Change in North Africa. Cambridge: Cambridge University Press.

Sayahi, Lotfi. 2018. "Spanish in Contact with Other Languages and Bilingualism across the Spanish-Speaking World". In: The Cambridge Handbook of Spanish Linguistics, ed. By Kimberly Geeslin, 459-477. Cambridge: Cambridge University Press.

Tilmatine, Mohand. 2009. "Ceuta y Melilla: elementos para una aproximación sociolingüística". In: Romanisierung in Afrika: der Einfluss des Französischen, Italienischen, Portugiesischen und Spanischen auf die indigenen Sprachen Afrikas, ed. by Thomas Stolz, Dik Bakker, and Rosa Salas Palomo, 17-30. Bochum: Universitätsverlag Dr. N. Brockmeyer.

Villa, Daniel J. and Susana V. Rivera-Mills. 2009. "An integrated multi-generational model for language maintenance and shift: The case of Spanish in the Southwest". Spanish in Context 6:1.26-42.

Ytsma, Jehannes, Maria Angels Viladot and Howard Giles. 2009. "Ethnolinguistic vitality and ethnic identity: some Catalan and Frisian data". International Journal of the Sociology of Language 108:1. 63-78. 